medRxiv preprint doi: https://doi.org/10.1101/2022.02.11.22270848; this version posted February 15, 2022. The copyright holder for this preprint (which was not certified by peer review) is the author/funder, who has granted medRxiv a license to display the preprint in It is made available under a CC-BY-ND 4.0 International license.

\title{
Strength and durability of antibody responses to BNT162b2 and CoronaVac
}

3 Benjamin J. Cowling*1,2, Irene O. L. Wong*1, Eunice Y. C. Shiu ${ }^{1}$, Amber Y. T. Lai ${ }^{1}$, Samuel

4 M. S. Cheng ${ }^{1}$, Sara Chaothai ${ }^{1}$, Kelvin K. H. Kwan ${ }^{1}$, Mario Martín-Sánchez ${ }^{1}$, Leo L. M.

5 Poon $^{1,3,4}$, Dennis K. M. Ip ${ }^{1}$, Gabriel M. Leung ${ }^{1,2}$, Nancy H. L. Leung ${ }^{\dagger 1,2}$, J. S. Malik

6 Peiris $^{\dagger 1,3,4}$

*Joint first authors with equal contribution

$9 \quad \dagger$ Joint senior authors with equal contribution

\section{Affiliations:}

12 1. WHO Collaborating Centre for Infectious Disease Epidemiology and Control, School of

13 Public Health, LKS Faculty of Medicine, The University of Hong Kong; Hong Kong Special

14 Administrative Region, China.

15 2. Laboratory of Data Discovery for Health; Hong Kong Science and Technology Park, Hong

16 Kong Special Administrative Region, China.

17 3. HKU-Pasteur Research Pole, School of Public Health, Li Ka Shing Faculty of Medicine,

18 The University of Hong Kong; Hong Kong Special Administrative Region, China.

19 4. Centre for Immunology and Infection; Hong Kong Science and Technology Park, Hong

20 Kong Special Administrative Region, China.

Corresponding authors: N. Leung leungnan@hku.hk and B. Cowling, bcowling@hku.hk

23 Word count (abstract): 50

24 Word count (main text): 1819 
medRxiv preprint doi: https://doi.org/10.1101/2022.02.11.22270848; this version posted February 15, 2022. The copyright holder for this preprint (which was not certified by peer review) is the author/funder, who has granted medRxiv a license to display the preprint in It is made available under a CC-BY-ND 4.0 International license.

\section{ABSTRACT}

27 We studied 2780 adults in Hong Kong who received CoronaVac inactivated virus vaccine

28 (Sinovac) and BNT162b2 mRNA vaccine (“Comirnaty”, BioNTech/Fosun Pharma). We

29 found stronger and more durable antibody responses to two doses of the mRNA vaccine, and

30 slightly stronger initial antibody responses to each vaccine in younger adults and women.

31 
medRxiv preprint doi: https://doi.org/10.1101/2022.02.11.22270848; this version posted February 15, 2022. The copyright holder for this preprint (which was not certified by peer review) is the author/funder, who has granted medRxiv a license to display the preprint in It is made available under a CC-BY-ND 4.0 International license

\section{INTRODUCTION}

33 Vaccines for coronavirus disease 2019 (COVID-19) provide protection against infection and can also ameliorate disease severity if breakthrough infections occur [1]. Protection against infection is likely mediated through antibodies, and the effectiveness of different vaccine technologies against mild symptomatic infection has been shown to correlate with the strength of neutralizing antibody responses to those vaccines [2-4]. In particular, antibody responses after receipt of inactivated COVID-19 vaccines have been shown to be somewhat weaker than antibody responses to mRNA vaccines $[5,6]$, although $\mathrm{T}$ cell responses are more comparable between the two vaccine technologies [6]. There are relatively fewer studies comparing rates of antibody waning over time, particularly with inactivated vaccines $[7,8]$.

In Hong Kong, two vaccines have been made available to the general public through a mass vaccination program since early 2021, the CoronaVac inactivated virus vaccine (Sinovac) and the BNT162b2 mRNA vaccine ("Comirnaty", BioNTech/Fosun Pharma). As of 11 February 2022, 11.7 million vaccine doses have been administered, with $74 \%$ of the population of about 7.4 million residents receiving at least one vaccine dose, $67 \%$ receiving at least two doses, and $16 \%$ receiving three doses. Of the 11.7 million doses administered to date, 4.5 million were CoronaVac and 7.2 million were BNT162b2. Here, we followed up 50 vaccinated individuals in Hong Kong to study the strength and durability of antibody 51 responses to vaccination for up to six months after the second dose.

\section{METHODS}

\section{Recruitment and Follow-up of Participants}

We analyzed data from two ongoing community-based cohort studies of infections and

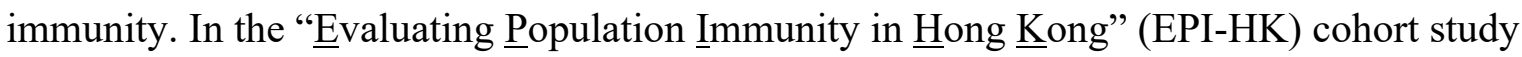


medRxiv preprint doi: https://doi.org/10.1101/2022.02.11.22270848; this version posted February 15, 2022. The copyright holder for this preprint (which was not certified by peer review) is the author/funder, who has granted medRxiv a license to display the preprint in It is made available under a CC-BY-ND 4.0 International license.

which was initially designed to study influenza and later also expanded to COVID-19, we enrolled individuals from the community starting in July 2020, and included individuals regardless of COVID-19 vaccination status. For analyses reported here we include the subset of study participants who were aged $\geq 18 \mathrm{y}$ and have received two doses of COVID-19 vaccination. Blood samples are collected from each participant at approximately six-month intervals, with additional blood samples collected one month after any dose of COVID-19 vaccination.

In the "COVID-19 VAccine Research" (COVAR) cohort study which aims to study vaccine immunogenicity and long-term antibody responses in COVID-19 vaccine recipients, we enrolled adults $\geq 18 \mathrm{y}$ of age from the general community and from Community Vaccination Centres. In the initial protocol we aimed to enroll individuals shortly before receiving the first dose of any COVID-19 vaccine in Hong Kong, this was later relaxed to allow enrollment of individuals after receiving one or more vaccine doses. Blood samples are collected from each participant at baseline, one month after any dose of COVID-19 vaccination, and at 6, 12, 24 and 36 months after the second dose of vaccination.

Similar data are collected from participants in both studies, including information on demographics and socio-economic status, underlying medical conditions and regular medication use, and the type and dates of any COVID-19 vaccine doses received. Participants receive coupons worth HK\$100 (approximately US\$13) at each blood draw.

\section{Ethics}

Written informed consent was obtained from all participants. The study protocols were approved by the Institutional Review Board of the University of Hong Kong. 
medRxiv preprint doi: https://doi.org/10.1101/2022.02.11.22270848; this version posted February 15, 2022. The copyright holder for this preprint (which was not certified by peer review) is the author/funder, who has granted medRxiv a license to display the preprint in It is made available under a CC-BY-ND 4.0 International license.

\section{Laboratory Methods}

Sera were extracted from the clotted blood samples within 24 hours after collection, divided into 2-4 aliquots, and stored at $-80^{\circ} \mathrm{C}$ until subsequent serologic testing. Samples were tested with an ELISA for spike receptor binding domain and a surrogate virus neutralization test (sVNT) as previously described [9]. We previously demonstrated that both assays can be used as proxy for neutralizing antibody against SARS-CoV-2 as measured by plaque reduction neutralization test with live virus [10].

We obtained sVNT kits from GeneScript USA, Inc, New Jersey and the tests carried out according to the manufacturer's instructions. The $\%$ inhibition of each serum was calculated as Inhibition $(\%)=(1-$ Sample OD value/Negative Control OD value $) \times 100$. Inhibition (\%) of $\geq 30 \%$ was regarded as a positive result while $<30 \%$ was considered negative [9].

ELISA was carried out as previously described [9]. 96-well ELISA plates (Nunc MaxiSorp, Thermo Fisher Scientific) were coated overnight with 100 ng per well of the purified recombinant RBD protein in PBS buffer. The plates were then blocked with $100 \mu$ of

99 Chonblock blocking/sample dilution ELISA buffer (Chondrex Inc, Redmon, US) and

100 incubated at room temperature for $2 \mathrm{~h}$. Each serum or plasma sample diluted 1:100 in

101 Chonblock blocking/sample dilution ELISA buffer was added to duplicate wells and 102 incubated for $2 \mathrm{~h}$ at $37^{\circ} \mathrm{C}$. After washing with PBS containing $0.1 \%$ Tween 20 , horseradish 103 peroxidase (HRP)-conjugated goat anti-human $\operatorname{IgG}(1: 5,000$, GE Healthcare) was added for 1

$104 \mathrm{~h}$ at $37^{\circ} \mathrm{C}$. The ELISA plates were then washed in PBS with $0.1 \%$ Tween 20 . Subsequently, $105100 \mu \mathrm{L}$ of HRP substrate (Ncm TMB One; New Cell and Molecular Biotech Co. Ltd, 106 Suzhou, China) was added into each well. After 15 min incubation, the reaction was stopped 
medRxiv preprint doi: https://doi.org/10.1101/2022.02.11.22270848; this version posted February 15, 2022. The copyright holder for this preprint (which was not certified by peer review) is the author/funder, who has granted medRxiv a license to display the preprint in It is made available under a CC-BY-ND 4.0 International license.

by adding $50 \mu \mathrm{L}$ of $2 \mathrm{M} \mathrm{H}_{2} \mathrm{SO}_{4}$ solution and analyzed on a Sunrise (Tecan, Männedorf, Switzerland) absorbance microplate reader at $450 \mathrm{~nm}$ wavelength. Optical density above 0.5 was considered a positive result.

\section{Statistical Analysis}

We assessed mean antibody levels measured by ELISA (optical density, OD) and sVNT (\% inhibition) after the first and second dose of COVID-19 vaccination. It was recommended that individuals should receive their second dose 21 and 28 days after the first dose for BNT162b2 and CoronaVac, respectively. We did not include any samples collected after receipt of a third dose, or any samples collected after a confirmed SARS-CoV-2 infection. Differences in antibody levels between vaccine type overall or within each category of age or sex were compared using t-tests. To evaluate the duration after which antibody level fall below the manufacturer's defined sVNT threshold of seropositivity at $30 \%$ inhibition (Supplementary Information), we fitted a smoothing spline to antibody levels over time starting at 14 days and up to 180 days after receipt of the second dose. Statistical analyses were conducted using R version 4.1.2 (R Foundation for Statistical Computing, Vienna, Austria).

\section{RESULTS}

We included data from 2780 vaccinated individuals including 2172 from the EPI-HK study and 608 from the COVAR study who had provided at least one post-vaccination blood sample by 23 December 2021, contributing 1528 blood samples collected from 799 individuals who received CoronaVac (median age 59.4 years, $46.6 \%$ male), and 3939 blood samples collected from 1981 individuals who received BNT162b2 (median age 49.3 years, 
medRxiv preprint doi: https://doi.org/10.1101/2022.02.11.22270848; this version posted February 15, 2022. The copyright holder for this preprint (which was not certified by peer review) is the author/funder, who has granted medRxiv a license to display the preprint in It is made available under a CC-BY-ND 4.0 International license.

$44.7 \%$ male). Additional information on the demographics of study participants is provided in Appendix Table 1.

Antibody levels increased to moderate levels following two doses of CoronaVac (Figure 1A) compared to very high levels following two doses of BNT162b2 (Figure 1B). The mean sVNT antibody levels measured against ancestral virus at 14-42 days after the second dose for CoronaVac were 53.7\% (95\% confidence interval, CI: 51.2, 56.3) and for BNT162b2 were $94.3 \%$ (95\% CI: 93.8, 94.7), with significant differences between the two vaccines overall and within each age group (Appendix Table 2). For both vaccines, the observed postvaccination levels had a slight inverse correlation with age, and average levels were slightly higher in females than in males ( $\mathrm{p}$-values $<0.01$ for these within-group comparisons) (Appendix Table 2). Overall, antibody levels remained below the threshold of $30 \%$ after the second dose in $23 \%$ and $0.5 \%$ of participants who received CoronaVac and BNT162b2, respectively. In particular, the antibody levels did not reach the threshold of $30 \%$ in $51 \%$ of older adults $\geq 60$ years old who received CoronaVac vaccination.

Antibody levels started to decline gradually over time starting from one month after recipient of the second dose for both vaccines, with faster antibody waning in the recipients of CoronaVac (Figure 1C and 1D). In recipients of CoronaVac, the fitted curve for average antibody level fell below the threshold of $30 \%$ by around 4 months after second dose, while remaining elevated for at least six months in recipients of BNT162b2. Consistently, we continued to observe significant differences in antibody levels 4-6 months after vaccination between the two vaccines overall and within each age group (Appendix Table 3). The mean sVNT antibody levels at 120-180 days after the second dose overall were $21.2 \%$ (95\% CI: 16.9, 25.6) and 81.1\% (95\% CI: 78.0, 84.3) for CoronaVac and BNT162b2 respectively. 
medRxiv preprint doi: https://doi.org/10.1101/2022.02.11.22270848; this version posted February 15, 2022. The copyright holder for this preprint (which was not certified by peer review) is the author/funder, who has granted medRxiv a license to display the preprint in It is made available under a CC-BY-ND 4.0 International license.

Specifically, sVNT antibody levels fell to below the threshold of $30 \%$ in $84 \%$ of participants

who received CoronaVac, versus none among those who received BNT162b2. However, with a smaller sample size here we were not able to identify statistically significant differences by age or sex within each vaccine group. We also examined antibody levels by ELISA, finding similar comparative patterns of boosting and waning between the two vaccine types

161 (Appendix Figure 1).

\section{DISCUSSION}

Evidence on antibody boosting and waning after vaccination is important as it affects the potential timing of subsequent booster vaccine doses. Here, we demonstrate higher levels of antibody to SARS-CoV-2 following two doses of the mRNA vaccine BNT162b2 compared to two doses of the inactivated vaccine CoronaVac [5, 6], and longer durability of responses for BNT162b2 for at least six months following the receipt of a second dose $[7,11]$. Our finding of rapid waning of antibody following receipt of CoronaVac echoes previous reports $[7,11]$ and indicates that a third dose would likely be needed sooner, and indeed in Hong Kong third doses have been recommended at $\geq 3$ months after the second dose of CoronaVac. It is important to recognize, however, that protection against severe COVID could be retained even in spite of waning of protection from infection [12].

We found stronger responses to two doses of both vaccines in females and in younger adults, consistent with other studies. For example Uwamino et al reported similar observations in a cohort of 673 recipients of BNT162b2 [13], while Xu et al. reported stronger and more durable antibody responses in females and younger recipients of an inactivated vaccine [14]. 
medRxiv preprint doi: https://doi.org/10.1101/2022.02.11.22270848; this version posted February 15, 2022. The copyright holder for this preprint (which was not certified by peer review) is the author/funder, who has granted medRxiv a license to display the preprint in It is made available under a CC-BY-ND 4.0 International license .

difference, and stronger antibody responses in women have been reported for other vaccines

$181 \quad[15]$

There are a number of limitations of our study. First, we did not measure neutralizing antibody against live SARS-CoV-2 but used a surrogate neutralization assay which has a high correlation with live virus neutralization titers [16]. We did not assess antibodies against variants such as Delta or Omicron, but expect antibody levels to be reduced against variants as reported in other studies $[16,17]$. We did not assess $T$ cell responses which could contribute to protection against severe disease and could be less affected by variants [18].

In conclusion, we identified weaker boosting and faster waning of antibodies against SARS-

CoV-2 in recipients of CoronaVac compared to BNT162b2, and would expect this to correlate with lower levels of protection against symptomatic infection for CoronaVac. In individuals of any age or sex, BNT162b2 responses were stronger and more durable than responses to CoronaVac. The weaker and less durable responses following CoronaVac support earlier provision of third doses to persons who previously received two doses of this vaccine. 
medRxiv preprint doi: https://doi.org/10.1101/2022.02.11.22270848; this version posted February 15, 2022. The copyright holder for this preprint (which was not certified by peer review) is the author/funder, who has granted medRxiv a license to display the preprint in It is made available under a CC-BY-ND 4.0 International license.

\section{ACKNOWLEDGMENTS}

200 We acknowledge colleagues including Jemmi Ho, Joyce Lau, Shadow Lau, Leslie Leung (EPI-HK study), Alex Chan, Vincent Fung, Raina Kwan, Lilly Wang, Benny Wong (COVAR study) and other part-time colleagues for technical support in preparing and conducting this study and enrolling participants; Anson Ho for setting up the database; Leo Luk, Karl Chan, John Li, Yonna Leung, Leo Tsang and Zacary Chai for laboratory support; Hetti Cheung, Victoria Wong, Bobo Yeung at HKU Health System; and King-man Ho, Cindy Man and other colleagues at the Community Vaccination Centres at Ap Lei Chau Sports Centre, Gleneagles Hospital and Hong Kong Central Library for facilitating the two cohort studies.

\section{FINANCIAL SUPPORT}

This project was financially supported by the Health and Medical Research Fund of the Food and Health Bureau of the Hong Kong SAR Government (project nos. COVID1903001 and COVID190126), the Theme-based Research Scheme (project no. T11-712/19-N) from the Research Grants Council from the University Grants Committee of Hong Kong, and the

214 Wellcome Trust (grant number: 221013/Z/20/Z). BJC is supported by an RGC Senior Research Fellowship (grant number: HKU SRFS2021-7S03).

\section{POTENTIAL CONFLICTS OF INTEREST}

218 BJC consults for AstraZeneca, Fosun Pharma, GSK, Moderna, Pfizer, Roche and Sanofi

219 Pasteur. The authors report no other potential conflicts of interest. 
medRxiv preprint doi: https://doi.org/10.1101/2022.02.11.22270848; this version posted February 15, 2022. The copyright holder for this preprint (which was not certified by peer review) is the author/funder, who has granted medRxiv a license to display the preprint in It is made available under a CC-BY-ND 4.0 International license.

\section{REFERENCES}

222 1. Wouters OJ, Shadlen KC, Salcher-Konrad M, et al. Challenges in ensuring global access to 223 COVID-19 vaccines: production, affordability, allocation, and deployment. Lancet 2021;

$224 \quad 397: 1023-34$.

2. Khoury DS, Cromer D, Reynaldi A, et al. Neutralizing antibody levels are highly predictive of immune protection from symptomatic SARS-CoV-2 infection. Nat Med 2021; 27:1205-11.

3. Feng S, Phillips DJ, White T, et al. Correlates of protection against symptomatic and asymptomatic SARS-CoV-2 infection. Nat Med 2021; 27:2032-40.

4. Earle KA, Ambrosino DM, Fiore-Gartland A, et al. Evidence for antibody as a protective correlate for COVID-19 vaccines. Vaccine 2021; 39:4423-8.

5. Lim WW, Mak L, Leung GM, Cowling BJ, Peiris M. Comparative immunogenicity of mRNA and inactivated vaccines against COVID-19. Lancet Microbe 2021; 2:e423.

6. Mok CKP, Cohen CA, Cheng SMS, et al. Comparison of the immunogenicity of BNT162b2 and CoronaVac COVID-19 vaccines in Hong Kong. Respirology 2021.

236 7. Kwok SL, Cheng SM, Leung JN, et al. Waning antibody levels after COVID-19 vaccination with mRNA Comirnaty and inactivated CoronaVac vaccines in blood donors, Hong Kong, April 2020 to October 2021. Euro Surveill 2022; 27.

8. Zeng G, Wu Q, Pan H, et al. Immunogenicity and safety of a third dose of CoronaVac, and

240 immune persistence of a two-dose schedule, in healthy adults: interim results from two

241 single-centre, double-blind, randomised, placebo-controlled phase 2 clinical trials. Lancet Infect Dis 2021.

9. Lau EH, Hui DS, Tsang OT, et al. Long-term persistence of SARS-CoV-2 neutralizing

244 antibody responses after infection and estimates of the duration of protection.

245 EClinicalMedicine 2021; 41:101174. 
medRxiv preprint doi: https://doi.org/10.1101/2022.02.11.22270848; this version posted February 15, 2022. The copyright holder for this preprint (which was not certified by peer review) is the author/funder, who has granted medRxiv a license to display the preprint in It is made available under a CC-BY-ND 4.0 International license.

10. Perera RAPM, Ko R, Tsang OTY, et al. Evaluation of a SARS-CoV-2 Surrogate Virus Neutralization Test for Detection of Antibody in Human, Canine, Cat, and Hamster Sera. J

248 Clin Microbiol 2021; 59.

11. Mok CKP, Cheng SMS, Chen C, et al. A RCT Using CoronaVac or BNT162b2 Vaccine as a Third Dose in Adults Vaccinated with Two Doses of CoronaVac. Am J Respir Crit Care Med 2022. vaccine up to 6 months in a large integrated health system in the USA: a retrospective cohort study. Lancet 2021; 398:1407-16.

13. Uwamino Y, Kurafuji T, Sato Y, et al. Young age, female sex, and presence of systemic adverse reactions are associated with high post-vaccination antibody titer after two doses of BNT162b2 mRNA SARS-CoV-2 vaccination: An observational study of 646 Japanese healthcare workers and university staff. Vaccine $\mathbf{2 0 2 2}$.

14. Xu QY, Xue JH, Xiao Y, et al. Response and Duration of Serum Anti-SARS-CoV-2 Antibodies After Inactivated Vaccination Within 160 Days. Front Immunol 2021; 12:786554. 15. Hussain M, Fatima M, Muhammad Iqbal S, et al. COVID-19 vaccine trials and sexdisaggregated data. Expert Rev Vaccines 2021:1-4. 16. Cheng SMS, Mok CKP, Leung YWY, et al. Neutralizing antibodies against the SARSCoV-2 Omicron variant following homologous and heterologous CoronaVac or BNT162b2 vaccination. Nat Med 2022.

266 17. Perez-Then E, Lucas C, Monteiro VS, et al. Neutralizing antibodies against the SARSbooster vaccination. Nat Med 2022. 
medRxiv preprint doi: https://doi.org/10.1101/2022.02.11.22270848; this version posted February 15, 2022. The copyright holder for this preprint (which was not certified by peer review) is the author/funder, who has granted medRxiv a license to display the preprint in It is made available under a CC-BY-ND 4.0 International license.

(a)

CoronaVac

(Sinovac)

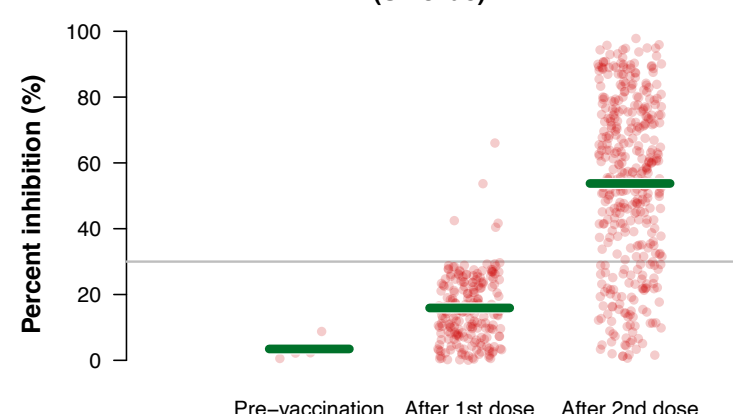

(c)

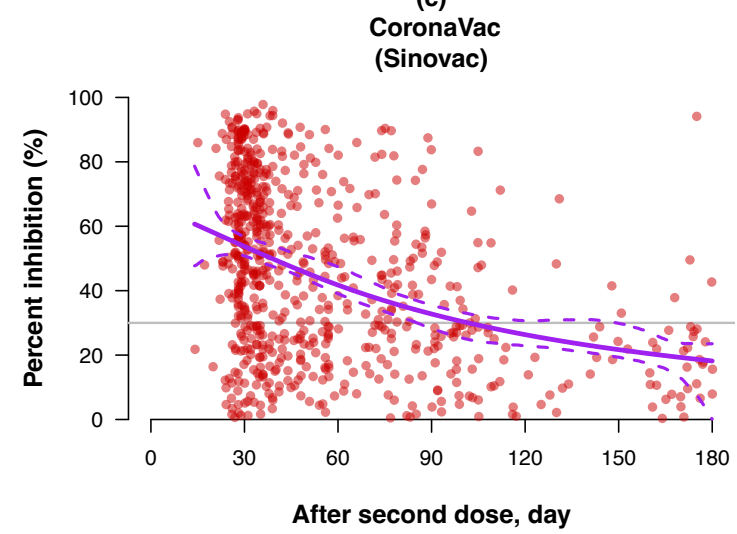

(b)

BNT162b2

(BioNTech/Fosun Pharma)

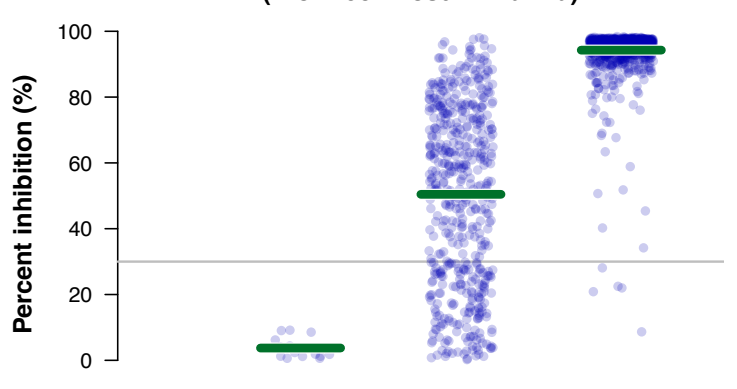

Pre-vaccination After 1st dose After 2nd dose

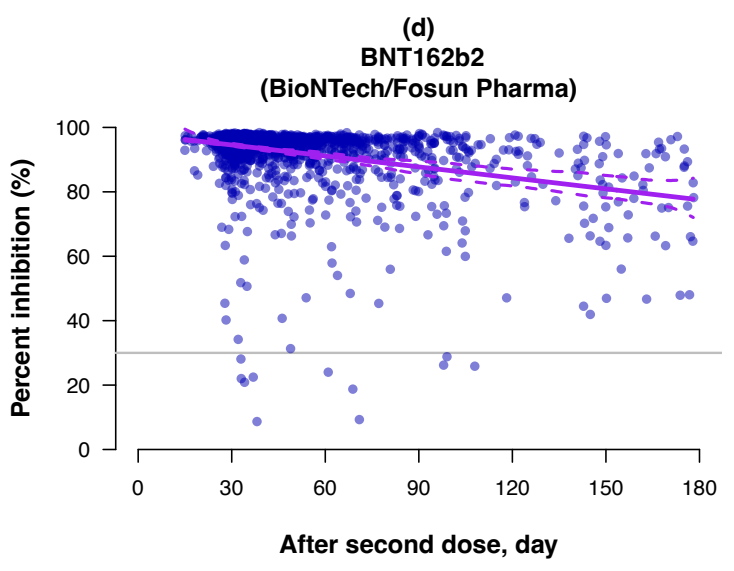

Figure 1: Post-vaccination rises followed by longer-term decay in neutralizing antibody levels against the ancestral SARS-CoV-2 virus after receipt of two doses of CoronaVac or BNT162b2 vaccination, measured by a surrogate virus neutralization test. Panels A and B show antibody levels prior to receipt of vaccination ("Pre-vaccination"), 14-35 days after receipt of the first dose but no later than the day of receipt of second dose ("After $1^{\text {st }}$ dose"), and 14-42 days after receipt of the second dose ("After $2^{\text {nd }}$ dose"), for an inactivated (CoronaVac) or mRNA (BNT162b2) vaccine respectively. Green lines represent mean \% inhibition in the respective time periods. Panels C and D show antibody levels between 14180 days after the receipt of a second dose of CoronaVac or BNT162b2, respectively. Solid purple lines represent the spline fit and dotted lines the associated 95\% pointwise bootstrap confidence intervals for the estimated changes over time in mean antibody levels. In all four panels, the grey horizontal line indicates the manufacturer's defined threshold for seropositivity at $30 \%$ inhibition. 
medRxiv preprint doi: https://doi.org/10.1101/2022.02.11.22270848; this version posted February 15, 2022. The copyright holder for this preprint (which was not certified by peer review) is the author/funder, who has granted medRxiv a license to display the preprint in It is made available under a CC-BY-ND 4.0 International license.
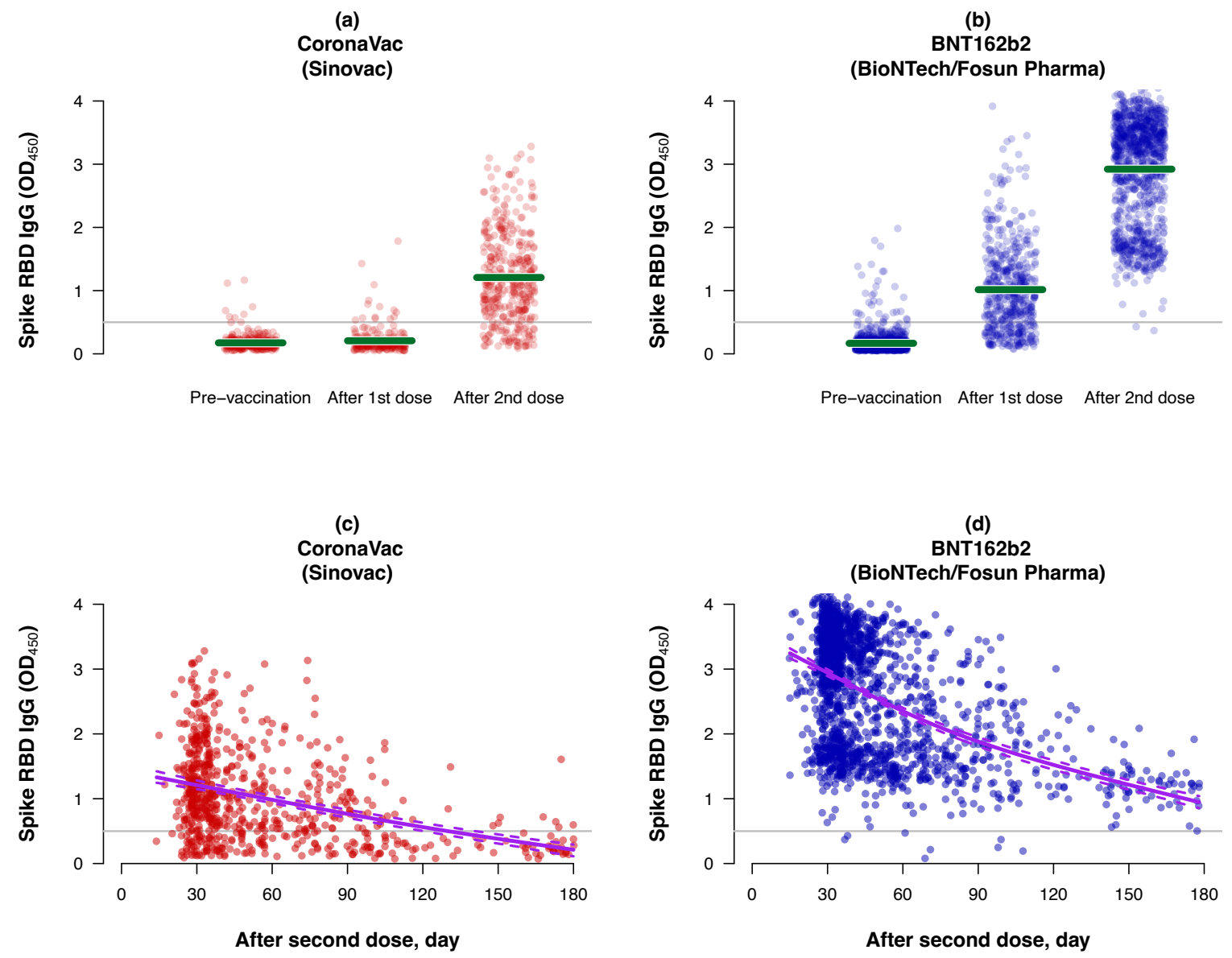

Appendix Figure 1: Post-vaccination rises followed by longer-term decay in IgG antibody levels against the ancestral SARS-CoV-2 virus after receipt of two doses of CoronaVac or BNT162b2 vaccination, measured by an ELISA assay against the receptor binding domain of the spike protein. Panels A and B show antibody levels prior to receipt of vaccination ("Pre-vaccination"), 14-35 days after receipt of the first dose but no

293 later than the day of receipt of second dose ("After $1^{\text {st }}$ dose"), and 14-42 days after receipt of 294 the second dose (“After $2^{\text {nd }}$ dose”), for an inactivated (CoronaVac) or mRNA (BNT162b2) vaccine respectively. Green lines represent mean optical density (OD) in the respective time periods. Panels C and D show antibody levels between 14-180 days after the receipt of a second dose of CoronaVac or BNT162b2, respectively. Solid purple lines represent the spline fit and dotted lines the associated $95 \%$ pointwise bootstrap confidence intervals for the estimated changes over time in mean antibody levels. In all four panels, the grey horizontal line indicates the manufacturer's defined threshold for seropositivity at OD of 0.5. 
medRxiv preprint doi: https://doi.org/10.1101/2022.02.11.22270848; this version posted February 15, 2022. The copyright holder for this preprint (which was not certified by peer review) is the author/funder, who has granted medRxiv a license to display the preprint in It is made available under a CC-BY-ND 4.0 International license.

\section{Appendix Table 1. Characteristics of study participants who received two doses of} inactivated vaccine (CoronaVac) or mRNA vaccine $(B N T 162 b 2)(n=2780)$. Participants from both the EPI-HK and COVAR studies who have antibody levels measured at least once between 14-180 days after recipient of the second dose are included.

\section{Inactivated vaccine \\ (CoronaVac) \\ $(n=799)$}

mRNA vaccine

(BNT162b2)

$(n=1981)$

\section{Number (\%) Number}

Age group, years

$18-29$

30-39

$40-49$

$50-59$

60-69

$\geq 70$

Male sex

Have a clinically-diagnosed chronic condition

Ever been a regular smoker (of one or more cigarettes a day)

Interval between first and second vaccination, days

$$
\text { 14-21 }
$$

$22-28$

$29-35$

$36-42$

$\begin{array}{rrrrr}29 & (3.6 \%) & 279 & (14.1 \%) \\ 43 & (5.4 \%) & 346 & (17.5 \%) \\ 114 & (14.3 \%) & 396 & (20.0 \%) \\ 231 & (28.9 \%) & 437 & (22.1 \%) \\ 284 & (35.5 \%) & 419 & (21.2 \%) \\ 98 & (12.3 \%) & 104 & (5.2 \%)\end{array}$

$372(46.6 \%)$

$885(44.7 \%)$

$235 \quad(29.4 \%) \quad 412 \quad(20.8 \%)$

$31 \quad(3.9 \%) \quad 100 \quad(5.0 \%)$ 
medRxiv preprint doi: https://doi.org/10.1101/2022.02.11.22270848; this version posted February 15, 2022. The copyright holder for this preprint (which was not certified by peer review) is the author/funder, who has granted medRxiv a license to display the preprint in It is made available under a CC-BY-ND 4.0 International license .

\section{Appendix Table 2. Mean sVNT levels measured against ancestral SARS-CoV-2 virus at} 14-42 days after the receipt of the second vaccine dose of an inactivated (CoronaVac) or mRNA (BNT162b2) vaccine, overall and by age and sex $(n=1431)$. Only participants from both the EPI-HK and COVAR studies who have antibody levels measured between 14-42 days after recipient of the second dose are included.

\begin{tabular}{|c|c|c|c|c|c|}
\hline \multirow[t]{2}{*}{ Group } & \multicolumn{2}{|c|}{$\begin{array}{c}\text { Inactivated vaccine } \\
(\text { CoronaVac) } \\
(n=378)\end{array}$} & \multicolumn{2}{|c|}{$\begin{array}{c}\text { mRNA vaccine } \\
(\text { BNT162b2) } \\
(n=1053)\end{array}$} & \multirow[t]{2}{*}{ p-value* } \\
\hline & sVNT & $(95 \% \mathrm{CI})$ & sVNT & $(95 \%$ CI) & \\
\hline Overall & 53.7 & $(51.2,56.3)$ & 94.3 & $(93.8,94.7)$ & $<0.001$ \\
\hline
\end{tabular}

Age group,

years

$\begin{array}{cccccc}18-29 & 69.6 & (58.8,80.4) & 96.5 & (96.2,96.8) & <0.001 \\ 30-39 & 54.0 & (44.1,63.9) & 94.7 & (93.7,95.6) & <0.001 \\ 40-49 & 53.1 & (46.1,60.2) & 94.4 & (93.6,95.3) & <0.001 \\ 50-59 & 56.9 & (52.5,61.3) & 94.0 & (93.2,94.9) & <0.001 \\ 60-69 & 51.6 & (46.8,56.4) & 93.4 & (92.1,94.6) & <0.001 \\ \geq 70 & 46.3 & (38.9,53.6) & 92.3 & (89.6,94.9) & <0.001 \\ \text { Male } & 48.0 & (43.9,52.0) & 93.3 & (92.5,94.2) & <0.001 \\ \text { Female } & 58.6 & (55.4,61.8) & 95.0 & (94.5,95.4) & <0.001\end{array}$

*p-values comparing antibody levels between the two vaccines overall and in each subset of participants (i.e. each row of this table) were estimated by t-tests. 
medRxiv preprint doi: https://doi.org/10.1101/2022.02.11.22270848; this version posted February 15, 2022. The copyright holder for this preprint (which was not certified by peer review) is the author/funder, who has granted medRxiv a license to display the preprint in It is made available under a CC-BY-ND 4.0 International license .

\section{Appendix Table 3. Mean sVNT levels measured against ancestral SARS-CoV-2 virus at} 120-180 days after the receipt of the second vaccine dose of an inactivated (CoronaVac) or mRNA (BNT162b2) vaccine, overall and by age and sex $(n=134)$. Only participants from both the EPI-HK and COVAR studies who have antibody levels measured between 120-180 days after recipient of the second dose are included.

\begin{tabular}{|c|c|c|c|c|c|}
\hline \multirow[t]{2}{*}{ Group } & \multicolumn{2}{|c|}{$\begin{array}{l}\text { Inactivated vaccine } \\
(\text { CoronaVac) } \\
(n=51)\end{array}$} & \multicolumn{2}{|c|}{$\begin{array}{l}\text { mRNA vaccine } \\
\text { (BNT162b2) } \\
(\mathbf{n}=\mathbf{8 3})\end{array}$} & \multirow[t]{2}{*}{ p-value* } \\
\hline & sVNT & $(95 \% \mathrm{CI})$ & sVNT & $(95 \%$ CI) & \\
\hline Overall & 21.2 & $(16.9,25.6)$ & 81.1 & $(78.0,84.3)$ & $<0.001$ \\
\hline
\end{tabular}

Age group,

years ${ }^{\dagger}$

$\begin{array}{crcccr}18-39 & -\dagger \dagger & - & 85.8 & (80.8,90.7) & <0.001 \\ 40-59 & 23.9 & (16.1,31.6) & 79.3 & (74.3,84.2) & <0.001 \\ \geq 60 & 18.7 & (14.7,22.8) & 78.9 & (72.1,85.7) & <0.001 \\ \text { Male } & 16.5 & (13.4,19.7) & 80.7 & (75.9,85.6) & <0.001 \\ \text { Female } & 24.8 & (17.6,32.0) & 81.5 & (77.3,85.7) & <0.001\end{array}$

*p-values comparing antibody levels overall and in each subset between the two vaccines (i.e. each row of this table) were estimated by t-tests.

Due to smaller sample sizes we used broader age groups in this analysis compared to the analysis shown in Appendix Table 2.

†Not estimated 